\title{
herbage SeEd: PRODUCtION AND Research - A REVIEW OF 50 YEARS
}

M.P. Rolston and P.T.P. Clifford

Grasslands Division, DSIR, Palmerston North and Lincoln

\begin{abstract}
By 1938 a small herbage seed industry was well established in New Zealand after the introduction of a system of seed certification and the establishment of a Government plant breeding station. Production increased rapidly during the 1940 s, to level off and fluctuate around 22,000 tonnes annually. Perennial ryegrass and white clover now dominate production. and research on these 2 species is presented to illustrate advances in research and practices of seed production. In ryegrass over the last $\mathbf{5 0}$ years we have gained an understanding of the physiology of flowering, and the use of herbicides, fungicides, nitrogen fertiliser, plant growth regulators, and post harvest drying systems are widespread. In white clover, growth and the detrimental influence of high soil fertility and/or soil moisture are now understood. Pollination and insect pest control, grass removal, and causes of harvesting losses have been studied and incorporated into seed production.
\end{abstract}

Keywords: herbage seed, perennial ryegrass, white clover

\section{INTRODUCTION}

Herbage seed production in New Zealand dates more than 100 years, with exports in the 1880s of 1400 tonnes of grass seed: cocksfoot, ryegrass (Lolium spp.) and tall fescue (Festuca arundinacea) (McKay 1887). Problems of poor seed quality and lack of strain uniformity in the 1920s resulted in 1929 in a system of seed certification for grasses and clovers (Eaden 1980; Hampton 1984). Plant breeding of grasses and clovers began with the establishment in 1927 of a Government plant breeding station at Palmerston North, resulting in three cultivars being released in the early 1930s (Rumball 1983). The cultivars later became known as 'Grasslands Huia' white clover (Trifolium repens) 'Grasslands Ruanui perennial ryegrass (Lolium perenne) and 'Grasslands Turoa' red clover (T. pratense).

Thus the stage was set in the late 1930 s, the beginning of this 50 -year review period. Seed production was $7300 t$ in 1938, but it increased rapidly in the 1940s to level off and fluctuate around $22000 \mathrm{t}$, with a declining trend beginning in 1976 (Table 1). The growth in volume has been associated with two species, perennial ryegrass and white clover. Volumes of other species have been static or have declined; crested dogstail (Cynosurus cristatus), 1240 t (1947) to 200 t (1986); Chewings fescue (Festuca rubra) 1534 t (1947) to 11 t (1983) and also hybrid ryegras (Lolium $x$ boucheanum), cocksfoot, red clover, lucerne (Medicago sativa).

In a review of the herbage seed industry Rolston et al. (1988) reported a farmgate value of herbage seed of $\$ N Z 40$ million. Seed exports are a major component of the industry averaging $7500 t(1982 / 86 ; 14000 t$ in 1987). Seed is exported to more than 30 countries, the major markets being the EEC, Australia and the USA

This paper reviews research on herbage seed using two species, perennial ryegrass and white clover, to illustrate advances. Average yields of these well researched species have increased, but are still low compared with those of good specialist growers and the best research yields (Table 2). 
Table 1: Quantities of machine dressed herbage seed produced in New Zealand (1000 t/year)

\begin{tabular}{|c|c|c|c|c|c|c|c|}
\hline \multirow[t]{2}{*}{ Period } & \multirow[t]{2}{*}{ Total } & \multicolumn{2}{|c|}{ Ryegrass } & \multirow[b]{2}{*}{ Cocksfoot } & \multicolumn{2}{|r|}{ Clover } & \multirow[b]{2}{*}{ Other } \\
\hline & & $\begin{array}{l}\text { Perennial } \\
+ \text { hybrid }\end{array}$ & Annual & & White & Red & \\
\hline $1938-42$ & 11.8 & 6.5 & 1.6 & & 0.7 & 0.8 & 1.4 \\
\hline 1943-47 & 18.5 & 6.8 & 3.3 & 1.0 & 1.8 & 1.4 & 2.4 \\
\hline $1948-52$ & 20.5 & 11.9 & 1.2 & 0.6 & 2.6 & 1.5 & 2.7 \\
\hline $1953-57$ & 23.0 & 15.4 & 1.1 & 0.5 & 2.7 & 1.1 & 2.2 \\
\hline $1958-62$ & 17.7 & 11.2 & 0.9 & 0.7 & 2.2 & 1.0 & 1.7 \\
\hline 1963-67 & 25.6 & 16.5 & 1.8 & 0.9 & 3.4 & 1.1 & 1.9 \\
\hline $1968 \cdot 72$ & 24.7 & 15.2 & 2.5 & 1.0 & 2.5 & 0.9 & 2.5 \\
\hline 1973.77 & 22.8 & 13.0 & 3.0 & 0.6 & 3.9 & 0.8 & 1.5 \\
\hline $1978-82$ & 20.8 & 11.2 & 1.8 & 0.6 & 5.4 & 0.7 & 1.1 \\
\hline $1983-87$ & 19.1 & 9.8 & 2.1 & 0.4 & 5.5 & 0.5 & 0.8 \\
\hline
\end{tabular}

Table 2: Trends in national seed yields ( $\mathrm{kg} / \mathrm{ha}$ ) compared with good specialist growers and research

\begin{tabular}{|c|c|c|c|c|}
\hline \multirow[t]{2}{*}{ Species } & \multicolumn{2}{|c|}{ National average } & \multirow{2}{*}{$\begin{array}{l}\text { Good } \\
\text { specialist } \\
\text { grower }\end{array}$} & \multirow[t]{2}{*}{ Research+' } \\
\hline & $1942-44$ & 1984066 & & \\
\hline Ryegrass & 350 & 585 & $1 Z 00-1500$ & 2900 (1) \\
\hline Cocksfoot & 140 & 305 & $600-900$ & $1350(2)$ \\
\hline Browntop & 135 & 135 & $300-500$ & $750(3)$ \\
\hline White clover (huia) & 120 & 230 & 500.900 & $1330(4)$ \\
\hline Red clover (Hamua) & 140 & 160 & $400-800$ & $1230(5)$ \\
\hline
\end{tabular}

- Higher specialist yields have been achieved but not consistently.

- * Hand harvested.

(1) Hampton et al. 1985.

(2) Rolston \& Hare 1986(a)

(3) Rolston 8 Hare 1986(b).

(4) Clifford 1985(a)

(5) Clifford 1979(b)

\section{PERENNIAL RYEGRASS}

A detailed management guide for perennial ryegrass seed production in the 1950s (Garrett 1957) illustrates the state of knowledge then. Herbicides were not discussed, and the importance of fallows to keep land clean of weeds was highlighted. Seeding rates of $22 \mathrm{~kg} / \mathrm{ha}$ were recommended, although rates of 33 to $44 \mathrm{~kg} / \mathrm{ha}$ were still being used. Overgrazing was noted as a problem to avoid, with recommendations that crops should be closed no later than 1 September in drier areas and mid September in others. Nitrogen fertiliser was recommended, but Garret notes only a relatively small scale use of nitrogenous fertilisers.

Discussing the difficulties of determining the time of cutting, Garrett notes the popular method of sweeping a hat through the crop and examining the number of seeds caught, and commenting "if a large number [of seeds] fall [into the hat] it should have been cut two or three days previously". He notes that under normal conditions the seed stalks are standing (a sure sign of a light crop by today's standards). The crop was either cut with a binder or mown into a windrow, left for a minimum of 7- 9 days, and harvested into bags which were allowed to field dry, weather permitting.

\section{Physiology of flowering}

Initial research focused on the physiological processes governing seed production with work by Hill $(1971,1980)$ and Langer (1972) on the origin, position and contribution of individual tillers, which laid the foundation for management research. 


\section{Sowing and grazing}

Sowing rates of $20 \mathrm{~kg} / \mathrm{ha}$ are still common, but specialist growers have reduced their sowing rates to $8-12 \mathrm{~kg} / \mathrm{ha}$ Most crops are established with white clover. The grazing recommendations of Garrett (1957) including time of closing (mid September) for most areas are unchanged.

\section{Fertiliser}

Research on the role of nitrogen rates and timing in seed yield and components by Field-Dodgson (1971) illustrated the importance of increasing seed head number as a component of increased seed yield. Brown (1980) introduced the time of $\mathrm{N}$ application with the concept of "elongation N". The use of autumn N, although initially advocated (Hill 1972), generally did not enhance seed yields in subsequent trials (Rolston et al. 1985). Hampton et a/. (1985) suggested grass seed crops require $130 \mathrm{~kg} \mathrm{~N} / \mathrm{ha}$, and the need to determine soil residual $\mathrm{N}$ status as a component was recognised. Other elements have rarely been reported as limiting grass seed yields in New Zealand.

\section{Weeds}

Weeds as contaminants lowering seed quality have always been a problem, and the 1969 Weed and Pest Control conference had a 5-paper session on weed seeds in agriculture, including control methods in the field (Allen 1969); and seed cleaning (Hartley 1969). Noxious weeds such as wild oat (Avena fatua) (Allen et al. 1974) and nodding thistle (Carduus nutans) are still problems in some crops (Rolston et al. 1985). Most farmers use various herbicide mixtures for cereals on grass seed crops, and as a result the three most commonly occurring weeds in seed lots are annual grasses, soft brome (Bromus mollis), vulpia hair grass (Vulpia spp.) and annual poa (Poa annua) (Rolston et a/. 1985).

\section{Diseases and fungicides}

Latch (1980) reviewed diseases in herbage seed crops. Blind seed disease (Gloeotinia temulenta) was a significant problem in the 1940 s but since $1957 / 58$ only minor infections have occurred and this decline has been associated with increased use of nitrogen fertiliser, which suppresses apothecial formation. Stem rust (Puccinia graminis) is a more recent problem in New Zealand. The disease can lower yields by 5 fold (Latch \& Christensen 1988). A range of cereal fungicides gave excellent control. Even in the absence of leaf disease Hampton (1986a) reported increased seed yields with fungicides, associated with retarding leaf senescence and improved floret fertility. The use of fungicide applied immediately pre-flowering is now recommended.

\section{Plant growth regulators (PGRs)}

There has been strong interest in PGRs for manipulating grass seed crops since early trials on paclobutrazol showed enhanced yields associated with reduced lodging and increased fertile tiller density and seeds per spikelet (Hampton et al. 1985). The chemical has yet to be registered for seed crops in NZ, but became commercially available for horticulture in 1987. A re-evaluation of the effects of chlormequat chloride (CCC) showed consistent yield increases from 1.5 to $3.0 \mathrm{~kg}$ a.i./ha applied at stem elongation (mid to late September for most ryegrasses) (Hampton 1986b). The yield increase is not associated with lodging control. CCC was registered for ryegrass seed crops in 1987.

\section{Seed moisture, harvesting and drying}

The optimum time for cutting can be determined by seed moisture (42-45\%). The move to bulk heading in the late 1950 s led to some disastrous germination collapses from fungal (Aspergillus glaucus) heating. Crosbie (1980) pioneered the design of drying systems so that seed could be cooled and dried to $14 \%$ seed moisture for safe storage. 
Seed recovery

Early research (Langer 1980) emphasised the importance of achieving an optimum seed head density. Once optimum densities of $2000-2500$ heads $/ \mathrm{m}^{2}$ were being achieved Brown (1982) noted considerable variation in seed yield associated with the number of florets producing a saleable seed. Brown (1982) referred to this as seed recovery which ranged from (15-20\%), and much of the response to fungicides, PGR and nitrogen is explained by increasing seed recovery.

\section{WHITE CLOVER}

The first production boom started in the mid 1940s and came from ryegrasswhite clover sowings, with the use of header-harvesters markedly reducing the high pre-war seed losses associated with stacking for later threshing by a clover huller (Leitch 1949). In the mid 1940s 18000 ha, compared with 15000 ha now, were taken for seed. However, the national average seed yield was only $80 \mathrm{~kg} / \mathrm{ha}$ compared with today's $230 \mathrm{~kg} / \mathrm{ha}$. Post war, $400 \mathrm{~kg} / \mathrm{ha}$ was the upper limit of grower expectation, but commercial yiels are now reaching over $900 \mathrm{~kg} / \mathrm{ha}$ (Table 2). These major yield differences between the past and the present highlight the effect of research findings on crop management.

In the late 1950s grass grub and porina control with DDT reduced subsequent pasture loss associated with closing a field for seed. Proude (1965) showed that control of high infestations of casebearer moth could double seed yields, while Palmer-Jones et al. (1962) defined minimum hive density for pollination at 1 per 3 ha (later revised to 1 per ha - MAF 1986). Removal of grass competition by paraquat spraying increased seed yields by $400 \%$ depending on grass density in relation to timing and application rate (Leonard 1964). Minimising the higher loss potential in these pure clover, low bulk crops, was overcome by the development of the Murphy rotary-tyned pickup.

Clover growth physiolgy

The first agronomic paper on the influence of the environment on white clover seed production (Thomas 1961), was significant in laying the foundation from which Clifford worked. His research culminated in the development of a philosophy which has promoted grower understanding to a level whereby the limitations of a particular environment can be minimised.

Clover growth occurs at the stolon tip with either stolons or flowerheads, but never both, forming in leaf axils (Thomas 1961). Thus flowerhead-associated leaf numbers in the mature crop are related directly to seed yield (Clifford 1985a, b, $1986 \mathrm{~b}, 1987)$. Floral induction is promoted by low temperature and short days, which is the opposite to floral expression (Thomas 1961, 1980). Seed crops must (i) experience a winter, (ii) have sufficient space among plants to grow high numbers of flowerhead-associated leaves, which must be ensured by, (iii) minimising any deleterious effects of excess soil moisture and/or fertility in increasing leaf size at the cost of lowering seed yield (Clifford 1979, 1980, 1985a, b, 1986a, b, 1987).

Research has shown how to meet these requirements in some of the following ways. Autumn row-spaced sowings $(30-45 \mathrm{~cm})$ have (i) increased flexibility of the crop rotation; (ii) ensured space for floral expression; (iii) given economic returns from soils with higher than desirable moisture-holding capacity and/or high soil fertility, especially P levels; and (iv) enabled elimination of inter-row contaminants, thereby allowing cultivar change to meet market demands (Clifford 1977, 1979a, 1980, 1985a, 1985b, 1987; Clifford et al. 1985; McCartin 1985; Hampton et al. 1987; Seed Certification, Seed Quality Control, MAF, 1984). By using moistureretentive soils or irrigation the grower can close the crop to flower in mid November, thereby optimising flowering intensity around the longest day (Clifford 1979). 
Irrigation after closing should be applied at any sign of wilting to maintain growth (flowering) and fertilised ovule retention; application rates should be about $50 \%$ of moisture holding capacity (Clifford 1985a, 1986a, 1986b).

The combined effects of this research have been to rapidly increase the area of seed taken on lower fertility (Olsen $P=6-12$ ), free-draining irrigable soils (Freeman 1985). In this way, the effects of high fertility on increasing leaf size, which diminishes both flowerhead numbers and yields, are more easily controlled (Clifford 1980, 1985a, 1987). Additionally for these soils, the implied growth control has lessened the spring grazing requirement, thereby reducing fertile stolon tip loss at the additional expense of developing further competitive infertile stolons (Clifford 1980, 1987).

The quantifying of when, where and why seed losses occur from the range of machinery alternatives and harvesting processes used, has greatly improved grower understanding of the best choices in relation to crop condition at harvest (Clifford \& McCartin 1985).

\section{CONCLUSION}

Research has now provided the technology whereby the national average seed yields of ryegrass and white clover should be 1200 and $600 \mathrm{~kg} / \mathrm{ha}$ respectively rather than the present averages, which are less than half of these. In looking to the future Rolston et al. (1988) have suggested the herbage seed industry has to be competitive internationally if it is to grow. Producing high yields which generally have low costs per $\mathrm{kg}$ of seed using the technologies discussed is an important component of being competitive internationally, Other components include producing appropriate cultivars that are on Recommended Lists, and protected by Plant Variety Rights; maintaining high quality seed lots; having effective marketing, with national off-farm costs that are similar to those of competitors; and maintaining a technological edge with research programmes.

\section{References}

Allen. F.C. 1969. Weed control in small seed crops. Proceedings 22nd New Zealand Weed and Pest Control Conference: $138-42$

Allen, F.C.; Smallbridge, T.J.; Bourdot, G.W. 1974. Wild oat control for nyegrass seed production. Proceedings 27th NZ Weed and Pest Control Conference: 67-73.

Brown, KR. 1980. Recent grass seed studies in Canterbury. pp. 12-I 4. In Lancashire, J.A. (Ed.). Herbage seed production. Grasslands research and practice series No. 1. New Zealand Grassland Association.

Brown, KR. 1982. The inefficient conversion of floret populations to actual seed harvest. Proceedings 14th International Grasslands Congress, Lexington USA: 266-68.

Clifford, P.T.P. 1977. Cultural methods for 'Grassland Pitau' white clover seed crops. NZ journal of experimental agriculture 5: 147-I 49.

Clifford, P.T.P. 1979a. Effect of closing date on potential seed yields from 'Grasslands Huia' and 'Grasslands Pitau' white clovers. NZ journal of experimental agriculture 7: 303-306.

Clifford, P.T.P. 1979b. Effects of closing date on seed production of red clover cultivars. NZ journal of experimental agriculture 7: $369-74$.

Clifford, P.T.P. 1980. Research in white clover seed production. pp. 64-67. In Lancashire, J.A (Ed.). Herbage seed production. Grasslands research and practice series No. 1. Palmerston North: New Zealand Grassland Association.

Clifford, P.T.P. 198\%. Effect of leaf area on white clover seed production. pp. 25-31. In Hare, M.D. Brock, J.L. (Eds) Producing Herbage Seeds Grassland Research and Practice Series No. 2. Palmerston North: New Zealand Grassland Association.

Clifford P.T.P. 1985b. Effect of cultural practice on potential seed yield components of 'Grasslands Huia' and 'Grasslands Pitau' white clover. NZ journal of experimental agriculture 13: 301-306.

Clifford, P.T.P. 1986a. Effect of closing date and irrigation on seed yield and some of its components for the lateflowering cultivar 'Grassland 18' white clover. New Zealand journal of experimental agriculture 14: 271 . 277

Clifford. P.T.P. 1986b. Interaction between leaf and seed production in white clover (Trifolium repens L.). Journal Of applied seed production 4: $37-43$. 
Clifford P.T.P. 1987. Producing high seed yields from high forage producing white clover cultivars. Journal of applied seed production 5: 1-9

Clifford, P.T.P.; McCartin, S.J.M. 1985. Effects of preharvest treatment and mower and header types on seed loss and hard seed content at mowing, recovery and separation when harvesting a white clover seed crop. NZ journal of experimental agriculture 13: $307-16$.

Clifford, P.T.P.; Rolston, M.P.; Williams, W.M. 1985. Possible solutions to contamination of white clover seed crops by buried seed. pp. 57-73. In Hare, M.D., Brock J.L. (eds). Producing Herbage Seed. Grasslands Research and Practice Series No. 2. New Zealand Grassland Association.

Crosbie, C.J. 1980. Bulk grass seed drying and storage. pp. 94-95. In Lancashire, J.A (Ed.). Herbage seed production. Grasslands research and practice series No. 1. Palmerston North: New Zealand Grassland Association.

Eaden, J.D. 1980. The role of field inspection in seed certification. pp. 99-102. In Lancashire, J.A. (Ed.). Herbage Seed Production. Grasslands Research and Practice Series No. 2 Palmerston North: New Zealand Grassland Association

Field-Dodgson, J.R.C. 1971. The effect of nitrogen on negrass seed production M.Agri.Sci. Thesis, Lincoln College.

Freeman, C.Logan 1985. Factors affecting scale of enterprise. pp. 37-40. In Hare, M.D., Brock J.L. (Eds). Producing Herbage Seeds. Grasslands Research and Practice Series No. 2. Palmerston North: New Zealand Grassland Association.

Garrett, H.E. 1957. Small seeds in New Zealand farm management. Canterbury Agricultural College.

Hampton. J.G. 1984. Cereal and herbage seed certification in New Zealand - a history. pp. 3 In Official Seed Testing Station Annual Report Ministry of Agriculture.

Hampton, J.G. 1986a. fungicidal effects on stem rust, green leaf area, and seed yield in 'Grasslands Nui perennial ryegrass. NZ journal of experimental agriculture 14: 7-12.

Hampton, J.G. 1986b. The effect of chlormequat chloride application on seed yield in perennial ryegrass (Lolium perenne L.). Journal of applied seed production 4: 8-12.

Hampton, J.G.; Clemence, T.G.A.; McCloy, B.L. 1985. Chemical manipulation of grass seed crops. pp. 9-14. In Hare, M.D., Brock J.L. (Eds). Producing Herbage Seeds. Grasslands Research and Practice Series No. 2. Palmerston North, New Zealand Grassland Association.

Hampton, J.G.; Clifford, P.T.P.; Rolston, M.P. 1987. Quality factors in white clover seed production. Journal of applied seed production 5: $32-40$.

Hartley. J.R. 1969. Cleaner seed by machine dressmg. Proceedings 22nd Weed and Pest Control Conference: $143-148$.

Hill, M.J. 1971. A study of seed production in 'Grasslands Ruanui' perennial ryegrass (Lolium perenne); 'Grasslands Kahu' timothy (Phleum pratense) and prairie grass (Bromus unioloides). PhD Thesis, Massey University.

Hill M.J. 1972. The effects of time of application of nitrogen on seed yields of 'Grasslands Ruanui' ryegrass (Lolium perenneL.) Proceedings Agronomy Society of New Zealand 2: 5-I 0.

Hill, M.J. 1980 Temperate pasture grass-seed crops: formative factors. pp. 137-150. In Hebblethwaite, P. (Ed). Seed production. 28th Easter School in Agricultural Science, University of Nottingham.

Langer, R.H.M. 1972. How grasses grow. Studies in Biology No. 34. Edward Arnold.

Langer, R.H.M. 1980. Growth of the grass plant in relation to seed production. pp. 6-1 1. In Lancashire, J.A. (Ed.). Herbage Seed Production. Grasslands Research and Practice Series No. 1. Palmerston North: New Zealand Grassland Association

Latch, G.C.M. 1980 Importance of diseases in herbage seed production. pp. 36-40. In Lancashire, J.A (Ed.) Herbage seed production. Grasslands research and practice series No. 1. Palmerston North: New Zealand Grassland Association.

Latch, GC.M Christensen, M.J. 1988. Effect of myclobutanil and propiconazole on endophyte and rust fung in ryegrass. Proceedings 4 ist NZ Weed and Pest Control Conference: 126-I 28.

Leitch, C.C 1949. Seed production in New Zealand - white clover. NZ journal of agriculture 79: 59-64

Leonard, W.F. 1964. Grass suppression in clover seed crops. Proceedings 17th New Zealand Weed and Pest Contral Conference: $49-52$.

McCartin J. 1985. Alternative establishment strategies for white clover seed production. pp. 33-36. In Hare, M.D. Brock, J.L. (Eds). Producing Herbage Seeds. Grasslands Research and Practice Series No. 2 Palmerston North New Zealand Grassland Association.

MacKay, T. 1987. A manual of the grasses and forage-plants useful to New Zealand. Part 1. p. 164. Crown Land Department.

Ministry of Agriculture and Fisheries, 1984. Seed Certification, Seed quality control.

Ministry of Agriculture and Fisheries, 1986. Honey bees; Pollination of crop; Economic significance of management. Aglink FPP 860

Palmer-Jones, T.. Foster, I.W.; Jeffery, G.L. 1962. Observations on the role of the honey bee and bumble bee as pollinators of white clover (Trifolium repens Linn.) in the Timaru district and Mackenzie Country. NZ journa of agricullural research 5: 318-325.

Proude, C.K 1965. Chemical control of casebearer. Proceedings 18th NZ Weed and Pest Control Conference: 179-I 84. 
Rolston, M.P.; Brown, KR.; Hare, M.D.; Young, KA 1985. Grass seed production, weeds, herbicides and fertiliser pp. 15-22. In Hare, M.D., Brock J.L (Eds). Producing Herbage Seeds Grasslands Research and Prac tict? Series No. 2. Palmerston North: New Zealand Grassland Association.

Rolston, M.P.. Hampton, J.G.; Hare, M.D. 1988. Herbage Seed : Towards the year 2000. Proceedings Agronomy Society of New Zealand 17: 39-44.

Rolston, M.P.; Hare, M.D. 1986a Competitive effects of weeds on seed yield of first year grass seed crops Journal of applied seed production 4: 34-36.

Rolston, M.P.; Hare, M.D. 1986b. Herticides for grass seed crops 1. Seedling browntop, phalaris and tall fescue Proceedings 39th New Zealand Weed and Pest Control Conference: 45-48.

Rumball, W. 1983. Pasture plant breeding in New Zealand. pp, 215-220. In Wratt, G.S., Smith, H.C. (Eds). Plant breeding in New Zealand. Buttenworths.

Thomas, R.G. 1961. The influence of environment on seed production capacity in white clover (Trifolium repens) L. 1. Controlled enviroment studies. Australian journal of agricultural research 12: 227-36.

Thomas, R.G. 1980 Growth of white clover plant in relation to seed production. pp. 56-63. In Lancashire, J.A. (Ed.). Herbage seed production. Grasslands research and practice series No. 1. Palmerston North New Zealand Grassland Association. 